\title{
紙コーティング用ラテックスの技術開発について
}

\author{
日本合成ゴム株式会社エマルジョン事業本部 浜 口 千 里
}

\section{Recent developments of SB latexes for paper coating}

\author{
Chisato Hamaguchi \\ Emulsion Division, Japan Synthetic Rubber Co. Ltd
} \begin{abstract}
main bindu of paper coating. latexes are discussed.

(1) The function and characteristics of SB latexes.

(2) Recent required properties for SB latexes and its background.

(3) Paper coatings VS latex properties.

(4) Recent developments of SB latexes.
\end{abstract}

The performance of coated paper has been much influenced by SB latexes which are used as a

In this paper, the following relation ships between coated properties and characteristics of SB

Keywords : Coated paper, SB latex, Web-offset printability, Gravure printability, High solid coating

\section{1.はじめに}

情報化社会の進展に伴ない塗工紙の伸びは著しい。 塗工紙の生産量および品種の構成比率は市場ニーズの 移り変りとともに大きく変化している(表 1$)$ 。最近の 需要動向で注目すべき点は雑誌のビジュアル化，印刷 物の軽量化要請から軽量コート紙, 微塗工紙の需要が 急速に拡大していること, 一方, 生活文化の高度化, 多様化に伴ない高級塗工紙（高級アート紙，キャス卜 コート紙等) の需要も強く, これら二極化現象の中で ますます多様化していることである。塗工設備も需要 の伸びとともに大型化, 高速化, 自動化が一段と進み 新コーターの増設が行われ, 印刷業界でもオフ輪, グ ラ輪などの輪転化とともに, より高速化, 精密多色化 の傾向にある。塗工紙は白色顔料, バインダーを主成 分としこれに分散剤, 潤滑剤, 耐水化剂, 防腐剤その 他の各種助剤からなる塗料を塗布して製造されるが, 上記動向に対応して各種塗工原材料も改良開発がなさ れている。中でもラテックスは全塗料固形分に対し重 量比で $10 \%$ 強, 体積比で $20 \%$ 程度使用され, 塗工作業
性，塗工紙品質，印刷作業性等に大きな影響を及ぼし， 特に重要な役割を果しており, 最も改良開発が積極的 に行われている。紙加工用ラテックスの需要も急速に 伸びており (表 2), 過去 10 年間の平均伸び率は $10.0 \%$ 塗工紙の同伸び率 $7.8 \%$ を回っている。こ れは塗工速度アップや塗工品質がレベルアップしたた め, 塗料中のラテックスリッチ化がすすみ, またラテッ クスの使用比率の高い軽量コート紙, 微塗工紙の生産 量が急速に增加しているためと推定される。顔料塗工 分野ではSB 系ラテックスが 9 割以上を占めており, ここでは，SB系ラテックスに焦点をあて紙コーティ ング用ラテックスの技術開発動向について述べる。

\section{2. 紙コーティング用ラテックスの機能と特徵1)}

紙の白紙光沢, 白色度, 不透明度等の外観改良, 平 滑性，均一なインキ吸収性，印刷光沢とインキ保持性， シャープな網点再現性等の印刷適性を改良するため紙 コーティングが行われる。紙コーティングにおいてラ テックスは顔料粒子相互の接着と顔料と原紙を接着す るバインダー機能だけではなく, 塗料に適正な流動性, 
表 1 塗工紙の品種別生産量推移

（日本製紙連合会資料・暦年）

単位: $\mathrm{t}$

\begin{tabular}{c|c|c|c|c|c|c|c}
\hline 昭和 & アート紙 & コート紙 & $\begin{array}{c}\text { 軽 } \\
\text { コート量 }\end{array}$ & $\begin{array}{c}\text { その他 } \\
\text { 塗工紙 }\end{array}$ & 合 計 & 前年比 & $\begin{array}{c}\text { 指 } \\
(50 \text { 年=100) }\end{array}$ \\
\hline 50 & 136 & 619 & 69 & 94 & 918 & $\triangle 3.7 \%$ & 100 \\
\hline 51 & 153 & 691 & 79 & 140 & 1,063 & $+15.9 \%$ & 116 \\
\hline 52 & 144 & 695 & 81 & 148 & 1,067 & $+0.4 \%$ & 116 \\
\hline 53 & 158 & 799 & 103 & 154 & 1,213 & $+13.6 \%$ & 132 \\
\hline 54 & 175 & 876 & 135 & 174 & 1,360 & $+12.1 \%$ & 148 \\
\hline 55 & 171 & 992 & 155 & 207 & 1,525 & $+12.1 \%$ & 166 \\
\hline 56 & 153 & 922 & 163 & 216 & 1,453 & $\triangle 4.7 \%$ & 158 \\
\hline 58 & 171 & 955 & 185 & 243 & 1,553 & $+6.9 \%$ & 169 \\
\hline 59 & 189 & 988 & 207 & 244 & 1,628 & $+4.8 \%$ & 177 \\
\hline 60 & 180 & 1,068 & 253 & 256 & 1,758 & $+8.0 \%$ & 192 \\
\hline 61 & 187 & 1,149 & 285 & 262 & 1,884 & $+7.2 \%$ & 205 \\
\hline
\end{tabular}

表 2 紙加工用合成ゴムラテックス品種別出荷推移（国内向け）

(通産省統計・暦年)

単位: $\mathrm{t}$

\begin{tabular}{l|r|r|r|r|r|r|r}
\hline 昭和 & SBR & CR & NBR & その他 & 合 計 & 前年比 & $\begin{array}{c}\text { 指 } \\
(50 \text { 年 }=100)\end{array}$ \\
\hline 40 年 & 6,401 & 19 & 43 & 384 & 6,847 & & \\
\hline 45 年 & 24,531 & 176 & 167 & 3,118 & 27,992 & & \\
\hline 50 年 & 35,696 & 256 & 521 & 3,531 & 40,004 & $+4.5 \%$ & 100 \\
\hline 51 年 & 43,067 & 245 & 651 & 4,805 & 48,768 & $+21.9 \%$ & 122 \\
\hline 52 年 & 42,532 & 214 & 733 & 6,625 & 50,104 & $+2.7 \%$ & 125 \\
\hline 53 年 & 51,204 & 150 & 785 & 6,891 & 59,030 & $+17.8 \%$ & 148 \\
\hline 54 年 & 59,042 & 144 & 900 & 7,230 & 67,316 & $+14.0 \%$ & 168 \\
\hline 55 年 & 62,463 & 107 & 698 & 6,326 & 69,594 & $+3.4 \%$ & 174 \\
\hline 56 年 & 61,691 & 93 & 422 & 5,552 & 67,758 & $\triangle 2.6 \%$ & 169 \\
\hline 57 年 & 72,116 & 107 & 483 & 6,001 & 78,707 & $+16.2 \%$ & 197 \\
\hline 58 年 & 77,410 & 131 & 538 & 7,160 & 85,239 & $+8.3 \%$ & 213 \\
\hline 59 年 & 85,162 & 110 & 581 & 8,028 & 93,881 & $+10.1 \%$ & 235 \\
\hline 60 年 & 92,511 & 72 & 575 & 8,108 & 101,266 & $+7.9 \%$ & 253 \\
\hline 61 年 & 99,968 & 62 & 437 & 6,987 & 107,454 & $+6.1 \%$ & 269 \\
\hline 62 & 112,345 & 57 & 502 & 6,291 & 119,195 & $+10.9 \%$ & 298 \\
\hline
\end{tabular}


安定性を与えるとともに塗工紙の性質, 印刷適性の全 ての項目に影響を与えている。ラテックスはラジカル 乳化重合によって得られるが，ポリマーの分子量が高 い割には粘度が低くかつ後述する通り重合方法，共重 合モノマーの組合せ等により要求性能の多様化に対応 可能でありカゼイン，でんぶん等の水溶性天然バイン ダーとして以下のような大きな特徴をもっており，紙 コーティング用の主カバインダーとしての地位を確保 している。

（1）塗料の粘度を低下させ，高濃度化が可能である。

（2）接着力が強く，塗膜の耐水性が良い。

（3）カレンダー効果が出やすく，光沢，平滑性が向 上する。

（4）インキ保持性が良く，印刷光沢が向上する。

(5) 取り扱いが極めて簡便である。

(6) 品質が安定している。

\section{3. 紙コーティング用ラテックスに要求される 特性}

紙コーティング用ラテックスに要求される品質特性 は多岐にわたっており，塗工紙製造過程における作業 適性，印刷及び加工過程における塗工紙の品質に大別 される(表 3$)^{11}$ 。塗料の調製段階では自動調製が一般 化しており化学的安定性, 機械的安定性, 熱的安定性 の優れたラテックスが求められている。塗料のレオロ ジ一特性は塗工適性に大きな影響を及ぼすので重要で ある。Low-Shear 粘度は塗料のポンピング, 循環に, High-Shear 粘度と保水性はブレードコーターでの塗 工作業性にとって特に重要である。ラテックスは塗料 のレオロジー特性と塗工作業性に極めて大きな影響を 与え, 特に近年の高速, 高濃度塗工において重要な役 割を果している。ゲートロール等のロールコーターで

表 3 ラテックスに要求される特性

\begin{tabular}{|c|c|c|c|c|}
\hline \multirow{3}{*}{ 作 } & \multirow{3}{*}{ 業 } & \multirow{3}{*}{ 性 } & $\begin{array}{l}\text { コーティングカラー } \\
\text { 調製 }\end{array}$ & $\begin{array}{l}\text { (1)顔料, バインダ一, 助剤など } \\
\text { との相客性(化学的安定性) } \\
\text { (2)機械的安定性, 熱的安定性 }\end{array}$ \\
\hline & & & 塗工適性 & $\begin{array}{l}\text { (1)流動特性及び粘度安定性 } \\
\text { (2)保水性 } \\
\text { (3)低発泡性 } \\
\text { (4)バッキングロール污れ }\end{array}$ \\
\hline & & & $\begin{array}{l}\text { 乾燥及U゙カレンダー } \\
\text { 適性 }\end{array}$ & $\begin{array}{l}\text { (1)マイグレーション } \\
\text { (2)キュアリング効果 } \\
\text { (3)耐ダスティング }\end{array}$ \\
\hline \multirow{3}{*}{ 塗 } & & \multirow{3}{*}{$\begin{array}{l}\text { 紙 } \\
\text { 質 }\end{array}$} & 感覚的性質 & $\begin{array}{l}\text { (1)光学的性質 } \\
\text { (白紙光沢, 白色度, 不透明度 etc) } \\
\text { (2)感触（スティッフネス,高) } \\
\text { (3)無臭 }\end{array}$ \\
\hline & & & 印刷適性 & $\begin{array}{l}\text { (1)平滑性 } \\
\text { (2)印刷光沢 } \\
\text { (3)インキ受理性, 吸水着肉性 } \\
\text { (4)インキセット } \\
\text { (5)ピッキング強度 (ドライ,ウェット) } \\
\text { (6) 耐モトリング } \\
\text { (7)酎ブリスター性 (オフ輪) } \\
\text { (8)グラビア適性 (スペックル) }\end{array}$ \\
\hline & & & 用途適性 & $\begin{array}{l}\text { (1)ウェットラブ } \\
\text { (2)ブロッキング } \\
\text { (3)割れ抵抗 } \\
\text { (4)後加工適性 } \\
\text { (糊はけ性, BP適性, エンドレス適性) } \\
\text { (5)耐光性 } \\
\text { (6)食品, 医薬安全性 }\end{array}$ \\
\hline
\end{tabular}


表 4 塗工紙品質に及ぼすSB系ラテックスの性質

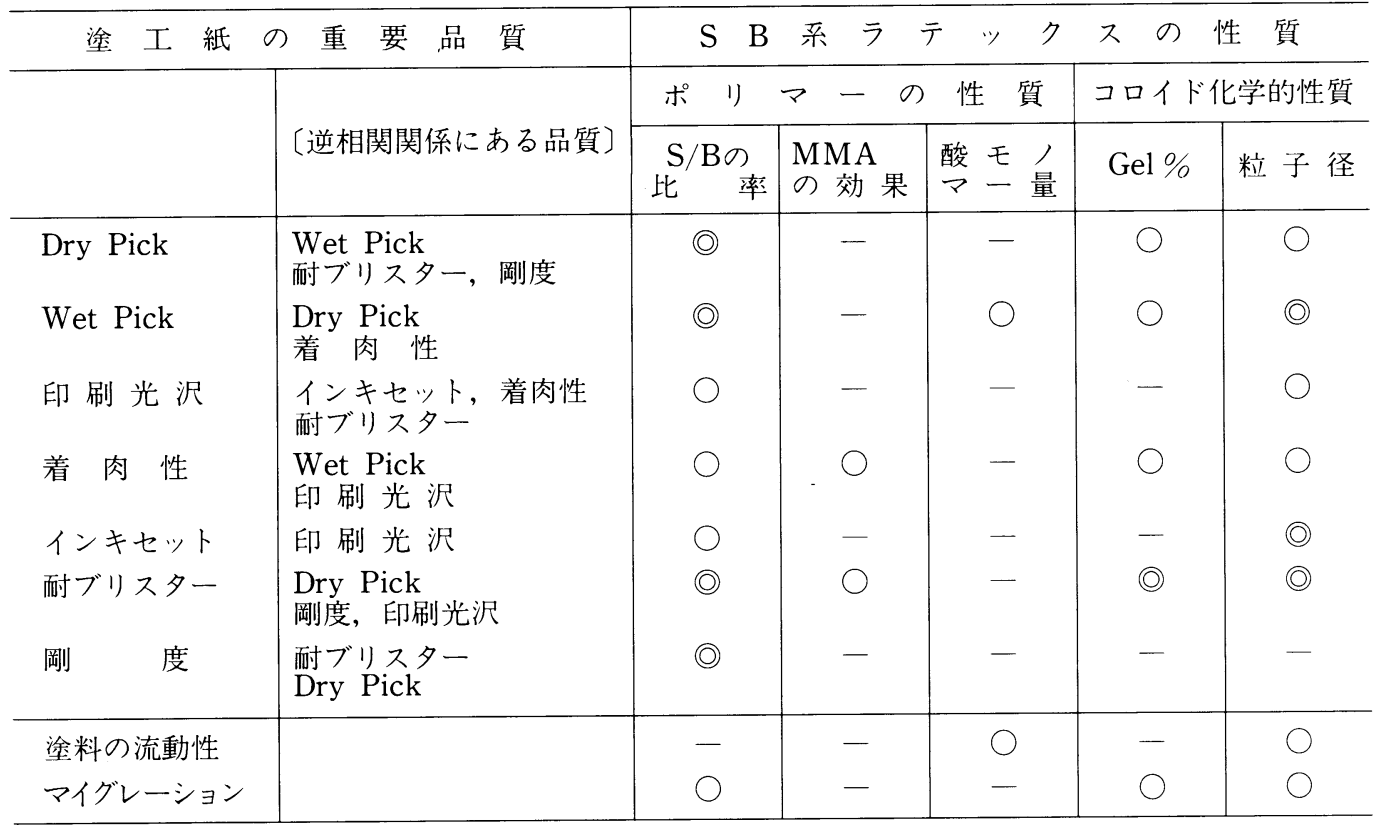

○は強い相関性の有るもの。○は相関性の有るもの。一は相関性の弱いものを示す

は塗工面のパターン，ガムアップを防止するためにも 流動性, 保水性, 機械的安定性に注意を払わねばなら ない。塗工紙の光学的性質は顔料の影響が大きいが, ラテックスにも強く要求されている（特に白紙光沢）。 塗工紙の軽量化にともないスティッフネス（腰）も要 求される。

印刷適性は印刷方式により要求性能が異なる。オフ セット印刷では夕ックの強いインキを使いかつ湿し水 を用いるため, ドライのピッキング強度とともに ウェット強度, 吸水着肉性が重視され, また印刷効果 を高めるため印刷光沢, 耐モトリング性, インキセッ 卜性も重要である。オフ輪特有の問題として両面べ夕 印刷部分での耐ブリスター性, グラ輪印刷ではハーフ トーン部でのスペックルの発生しないラテックスが求 められている。板紙塗工の場合, 上記印刷適性に加え, 製函加工され使用されるため糊付け適性, ブリスター パック適性, プレスコート適性等が要求される。

これら要求特性の中には表 $4^{2)}$ に示すごとく二律相 反する特性が多い。最近のコーティング技術，印刷技 術の著しい進展にともない, 従来よりもより厳しい条 件下での操業性をもち，かつより高度な品質バランス をもったラテックスが要求されている。

\section{4. ラテックス要因とコーティング特性}

前記した厳しい条件下での操業性能をもち，より高
度なラテックスを開発するためには, 製紙メーカーに おける原紙条件, 塗料処方, コーティングプロセス, 乾燥, 仕上げ条件, 及び印刷メ一カーにおける印刷プ ロセスとその条件, 塗工紙の使用条件等々とラテック スの重合要因, 特性要因との相互関係を的確に把握し て品質設計をしなければならない。実機操業及び実際 の印刷結果と相関性の高いテーブル評価法を確立する ことも極めて重要であり, 塗工層構造の解明も含めラ テックスメーカーではこの点にも注力している（図 1)。コーティング塗料及び塗工紙の品質に影響を及ぼ すラテックスの諸因子は, 大別するとポリマーの性質 と分散系のコロイド化学的性質に分けられ, さらに表 5 に示すごとく分類される。

現在, 市販されている SB 系ラテックスは単純なス チレンーブタジエン共重合体ではなく, 性能向上をはか るため多元共重合体となっている。 SB 系ラテックス の重合に使用されているモノマーの種類と配合比率, 各モノマーの使用目的を表 6 に示す。ラテックスの特 性と塗料及び塗工紙品質との関係については既に多く の紹介 ${ }^{2), 3), 4)}$ があるが改めて整理してみたい。1960 年代 初期にカルボキシ変性ラテックスが出現して以来, ラ テックスのコロイド化学的安定性は飛躍的に向上した。

ラテックスのコロイド化学的安定性は顔料や他の助 剂との相溶性や貯蔵安定性だけでなく, 塗料のレオロ ジー,バインダーマイグレーション, コーティングホー 


浜口 千 里

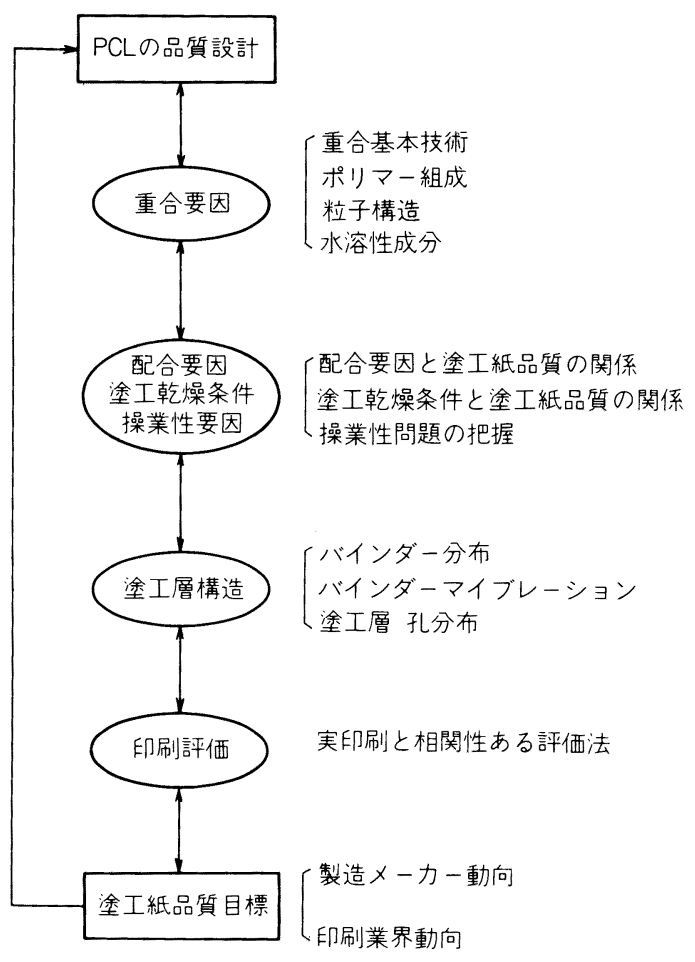

図 1 PCL の品質設計

ルドアウト，塗工層の構造等にも大きな影響を及ほし ており，カルボキシ変性は紙コーティング用ラテック スにとって欠かせないものとなっている。塗料のレオ ロジー特性はラテックスのコロイド化学的安定性だけ でなく, 粒径とその分布, 使用するカルボキシモノマー の種類と量, $\mathrm{pH} に よ り$ 影響をうける。高速ブレード塗 工での操業安定性はラテックスのコロイド化学的安定 性を増し, 粒径を小さくし, カルボキシ化の増加によ り改善される。接着強度は図 2 , 図 3 に示すようにう テックスの粒径が小さいほど，またカルボキシ変性度 をあげるほど強くなる。ドライ強度とウェット強度は ゲル含量によっても影響を受け，ドライ強度はゲル含 量の増加とともに強くなり, 一方ウェット強度はゲル

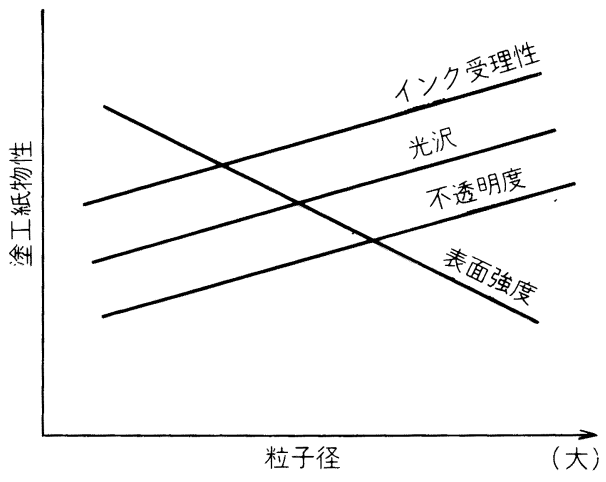

図 2 粒子径の塗工紙物性への影響

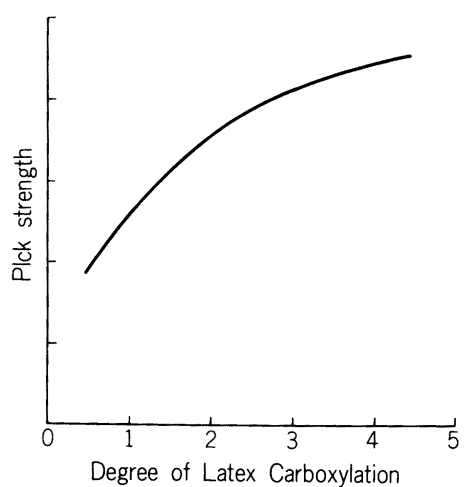

図 3 Pick Strength vs Latex Carboxylation

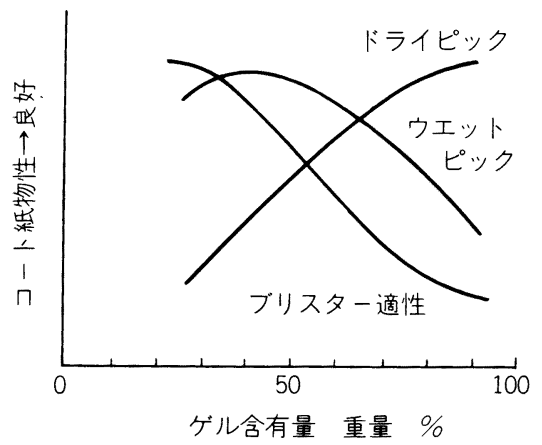

図 $4 \mathrm{SB}$ ラテックスのゲル含有率とコート紙物性の 関係

表 5 コーティング特性に及ぼすラテックスの諸因子

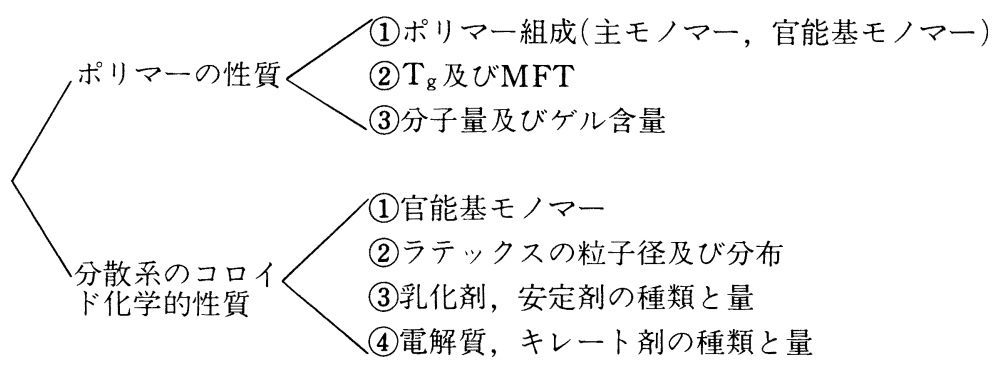


表 $6 \mathrm{SB}$ 系ラテックスの重合に使用される各種モノマーについて

\begin{tabular}{|c|c|c|c|}
\hline モノマー & 具体例 & 配合率 $(\%)$ & 使用目的 \\
\hline 脂肪族共役ジエン化合物 & ブタジエン & $15 \sim 60$ & 接着性 \\
\hline 芳香族ビニル化合物 & スチレン & $20 \sim 70$ & 腰, 白紙光沢 \\
\hline $\begin{array}{l}\text { ビニル系不飽和カルボン酸 } \\
\text { エステル化合物 }\end{array}$ & $\begin{array}{l}\mathrm{MMA} \\
\text { (メチルメタアクリレート) } \\
\text { メチルアクリレート } \\
\text { ブチルアクリレート }\end{array}$ & $5 \sim 40$ & $\begin{array}{l}\text { 耐光性 } \\
\text { 着肉性 }\end{array}$ \\
\hline ビニル系不飽和カルボン酸 & $\begin{array}{l}\text { アクリル酸 } \\
\text { フマル酸 } \\
\text { メタクリル酸 } \\
\text { イタコン酸 } \\
\text { マレイン酸 }\end{array}$ & $1 \sim 10$ & $\begin{array}{l}\text { 接着性 } \\
\text { 安定性 }\end{array}$ \\
\hline 他のビニル化合物 & & & \\
\hline $\begin{array}{l}\text { 〔シアノ基〕 } \\
\quad-\mathrm{C} \equiv \mathrm{N} \\
\qquad ア ミ ノ \text { 基 } \\
\quad-\mathrm{NH}_{2}\end{array}$ & $\begin{array}{l}\text { アクリロニトリル } \\
\text { ×タクリロニトリル } \\
\text { ビニルピリジン } \\
\text { ジメチルアミノエチル } \\
\text { メタクリレート }\end{array}$ & & $\begin{array}{l}\text { 印刷光沢 } \\
\text { 耐油性 } \\
\text { グラビア適性 } \\
\text { 着肉性 }\end{array}$ \\
\hline $\begin{array}{l}\text { 〔アミド基〕 } \\
\quad-\mathrm{CONH}_{2}\end{array}$ & $\begin{array}{l}\text { アクリルアミド } \\
\text { メタリリルアミド }\end{array}$ & $0 \sim 20$ & 接着性, 安定性 \\
\hline $\begin{array}{l}\text { [エポキシ基〕 } \\
-\mathrm{C}-\mathrm{C}\end{array}$ & $\begin{array}{l}\text { グリシジルアクリレート } \\
\text { グリシジルメタクリレート }\end{array}$ & & 接着性 \\
\hline $\begin{array}{l}\text { 〔水酸基〕 } \\
-\mathrm{OH}\end{array}$ & $\begin{array}{l}2 \text {-ヒドロキシエチルアルリレート } \\
2 \text {-ヒドロキシエチルメタクリレート }\end{array}$ & & $\begin{array}{l}\text { 接着性 } \\
\text { 安定性 }\end{array}$ \\
\hline
\end{tabular}

含量の低い方が一般的に強い(図 4 )。白紙光沢はおお むね表面平滑性に依存し，平滑性が高くなるほど白紙 光沢は高くなる。白紙光沢はバインダーレベルの増加 とともに低下し (図 5$)^{5), 6)}$, ラテックスの $\mathrm{T}_{\mathrm{g}}$ と乾燥条 件によっても影響を受ける(図 6) ${ }^{7)}$ 。図 $7^{8)}$ に示すよう に塗料を不安定化させると白紙光沢は低下する。また 有機ピグメントを無機ピグメントの一部を置換するこ とにより白紙光沢は向上する。有機ピグメントはスチ レンを主体としたカルボキシ変性ラテックスで白紙光 沢だけでなく，白色度，インキ受理性，着肉性，耐ブ リス夕一適性等も同時に向上する。印刷光沢は白紙光 沢と塗工層の空吵構造, インキとラテックスの相互作 用によって影響を受ける。ラテックスの粒径, ゲル量, アクリロニトリル量等と印刷光沢との関係を図 8 ～図 10 に示す9)。インキ受理性とインキ吸収性は印刷にお
ける重要な性質でこれに影響を及ぼす要因は多くある。 しかし最も重要な要因はバインダーレベルであり, バ インダーレベルの低い方がこれらの性質を向上させる。 一般的にラテックスの粒径が大きいほど, $\mathrm{T}_{\mathrm{g}}$ が高いほ ど, ゲル量が低いほど改善される。耐ブリスター適性 はオフ輪印刷に特有の現象で印刷後の乾燥工程で問題 となる。酢ビ系ラテックスは SB 系やアクリル系ラ テックスと比べ耐ブリスター性が優れているのは, 塗 工層の空隙率が高いだけではなく，高温においてポリ

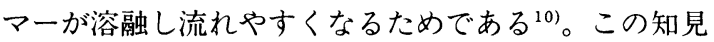
に基づいて, SB 系ラテックスではゲル量をコント ロールすることによって最適化をはかっている（図 4 )。塗料の表面被覆性は原紙の瀻維被覆性と紙の平滑 性に依存し, 塗工層構造は光学的性質, インキ受理性, 着肉性, 後加工適性に影響を及ぼす。ラテックスとピ 


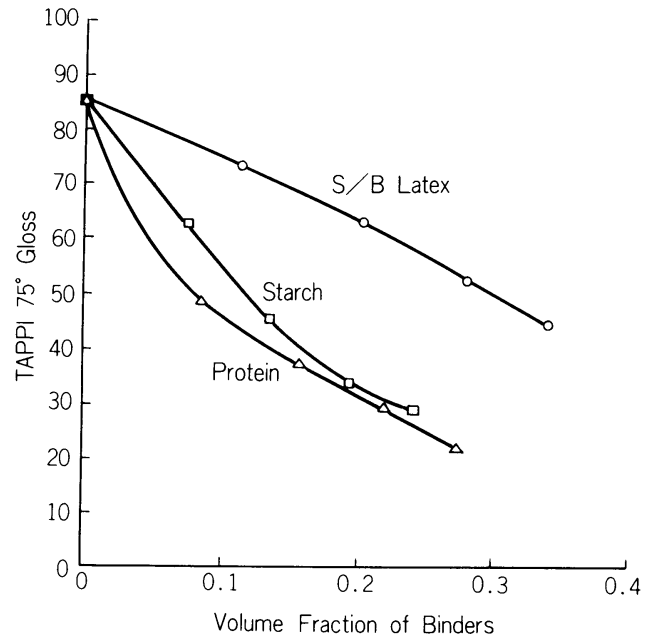

図 5 The Gloss of No.1 Clay Coatings Containing S/B Latex, Starch, and Protein vs Volume Fraction of Binder.

Substrate: Polyester Film

Finishing: Uncalendered

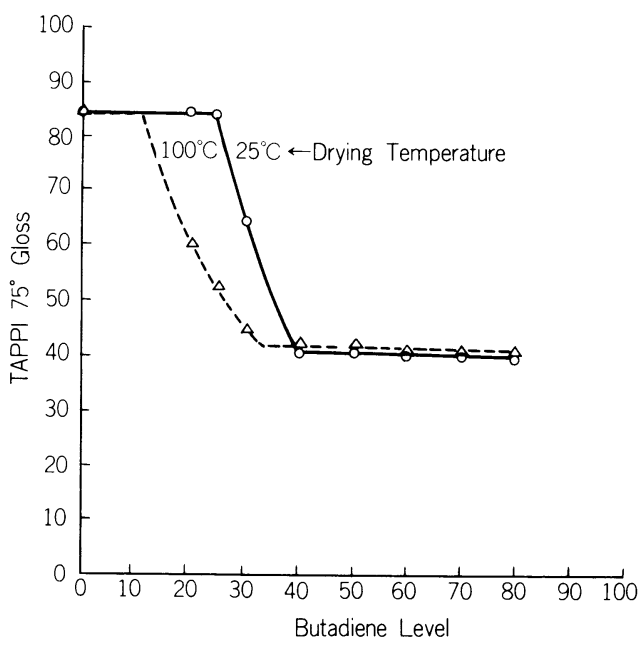

図 6 The Gloss of No.1 Clay/S/B Latex (100/20) Coatings vs Butadiene Level and Drying Temperature

グメントの相互作用を増すことにより表面被覆性と平 滑性は向上する。特にグラビア軽量コート紙の製造に は表面被覆性を向上させることは重要である。グラビ ア印刷では平滑性と圧縮性が影響する。平滑性はラ テックスとピグメントの相互作用をコントロールし， 塗粒の不動化点を下げることにより達成できる。図 11 にラテックスのブタジエン量とミッシングドットとの 関係を示す11)。バインダーマイグレーションは塗工紙

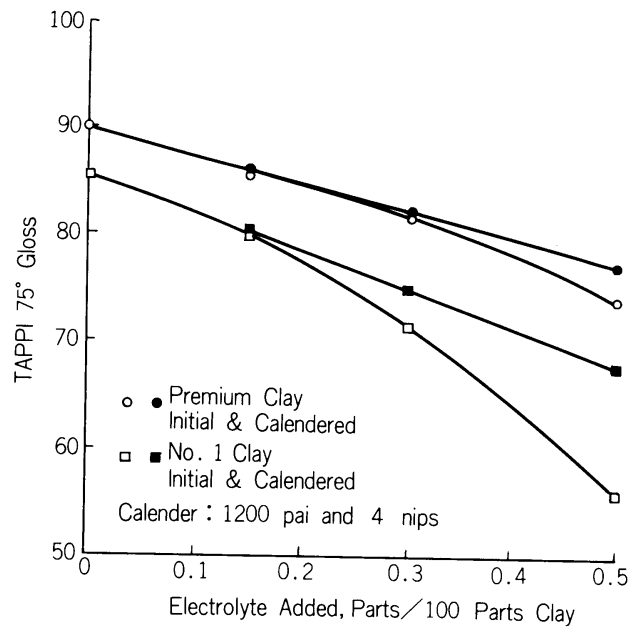

図 7 The Gloss of Clay Coatings vs Electrolyte Level

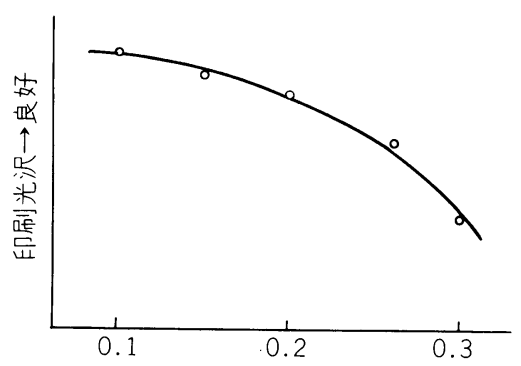

粒子径 $(\mu \mathrm{m})$

図 8 SBR 粒子径と印刷光沢の関係

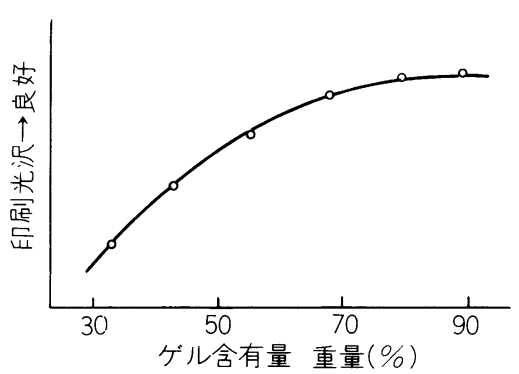

図 9 SBRのゲル含有量と印刷光沢の関係

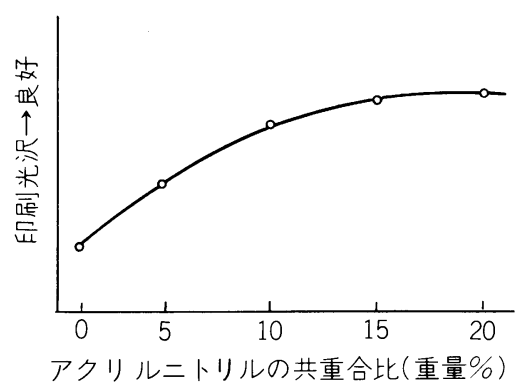

図 10 SBRのアクリルニトリル共重合比と印刷光沢 の関係 


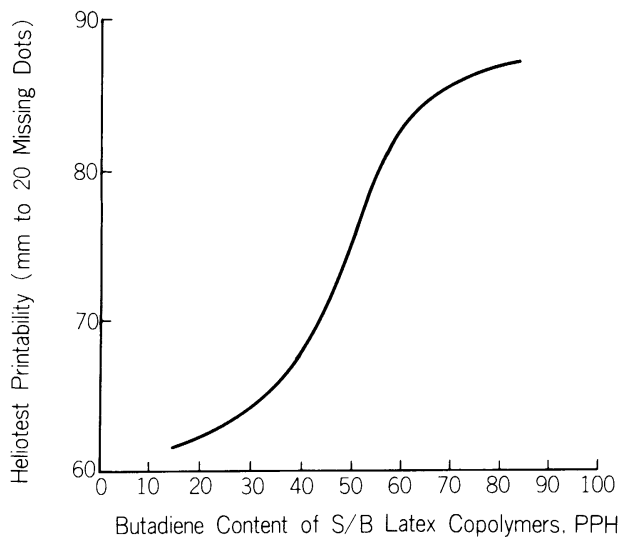

図 11 The Rotogravure Printability of S/B Latex Containing Clay Coatings vs Softness of Latex Polymers

Coating Formulation: No.1 Clay/Latex $(100 / 7)$

製造工程の乾燥段階で，塗工層内のバインダーが不均 一な分布となる現象として定義される。バインダーマ イグレーションが発生するとカレンダー工程でのダス ティング，印刷モトル，糊付性不良等の問題をひきお こす。一般的にはラテックスの粒径の大きいものほど, また塗料の固形分濃度が高いほどマイグレーションは 発生しにくいといわれている。

\section{5. 最近の紙コーティング用ラテックスの 改良動向}

1940 年代に合成ラテックスが紙コーティング用に 使用されはじめて以来, 塗工プロセスの変遷, 塗工技 術，印刷技術の進歩，塗工紙の用途多様化に対応しラ テックスの改良がすすめられてきた。既にラテックの 品質改良により塗料の特性, 塗工紙の品質, 印刷適性 が改良されることを述べてきた。ラテックスに対する 基本的な要求性能は変っていないが, 最近ではさらに 厳しい条件下での操業性に耐え，より高度な塗工紙品 質及び印刷適性を満足させる高品質のラテックスが求 められている。最近の塗工，仕上げ，印刷ニーズに対 しどのような品質展開をはかっているか，ラテックス の改良動向を公開された特許を主体に述べる。

1） ハイソリッド処方における高速塗工適性

塗工紙の生産性及び品質向上，コストダウンの観点 から塗料のハイソリッド化による高速化が積極的にす すめられ，より厳しい条件下での塗工作業性が要求さ れている。高速塗工においてストリーク，スクラッチ， ストラクタイト等が発生しない塗料とするためには
High Shear での流動性, 動的保水性を考慮したラテッ クスの品質設計が不可欠である。前述したように，ラ テックスの粒子径, 酸モノマーの種類, 量, 分布等の 最適化が行われる ${ }^{12,13)}$ 。2 つの別個の粒径分布を有寸 るバイモダルラテックス ${ }^{14)}$ や水相中のオリゴマー量を コントロールしたラテックス ${ }^{15)}$ がある。日本では高速 ブレード塗工の場合，フロクリンドクターをつけるこ とが一般的でありオフ輪塗工紙，グラ輪塗工紙を生産 する時バッキングロールに污れが発生し問題となる ケースがある。バッキングロールの污れにはラテック スポリマーの性質も大きく影響する。このためにラ テックスの耐水性, ラテックスフィルム, 塗料皮膜等 の水への再分散性，ラテックスポリマーの粘着性に注 目し改良が行われている。一般的な平判用，才フ輪用， グラ輪用ラテックスの $\mathrm{T}_{\mathrm{g}}$, ゲル量, 粒径とこれらの性 質との関係を表 7 に示す ${ }^{16)}$ 。バッキングロールの污れ と相関性があるこれら特性と塗工紙品質のバランス アップをはかるため，コアとシェルでポリマー組成が 異なるコア/シェル構造ラテックス ${ }^{17)}$, 特殊官能基モ ノマーの重合方法を工夫したラテックス ${ }^{18)}$ 等がある。

表 7 各種ラテックスの特性

\begin{tabular}{|c|c|c|c|c|c|}
\hline & \multirow{2}{*}{$\begin{array}{l}\text { 耐 } \\
\text { 水 } \\
\text { 性 }\end{array}$} & \multicolumn{2}{|c|}{ 再分散性 } & \multicolumn{2}{|c|}{ 粘 着 性 } \\
\hline & & $\begin{array}{l}\text { ラテッ } \\
\text { クス }\end{array}$ & カラー & ベトツ & ビール \\
\hline $\begin{array}{l}\text { 平 判 用 } \\
\text { ラテックス }\end{array}$ & $\triangle$ & 稤 & 0 & $\triangle$ & 0 \\
\hline $\begin{array}{l}\text { オフ輪用 } \\
\text { ラテックス }\end{array}$ & 0 & $\begin{array}{l}の \\
\text { 影 } \\
\text { 響 }\end{array}$ & $x$ & 0 & $x$ \\
\hline $\begin{array}{l}\text { グラ輪用 } \\
\text { ラテックス }\end{array}$ & $x$ & 莫」 & 0 & $x$ & $\triangle$ \\
\hline $\mathrm{T}_{g} \quad \uparrow$ & $\uparrow$ & $\rightarrow$ & $\uparrow$ & $\uparrow \uparrow$ & $\uparrow$ \\
\hline ゲル & $\downarrow \downarrow$ & $\rightarrow$ & $\uparrow \uparrow$ & $\uparrow$ & $\uparrow \uparrow$ \\
\hline PS & $\downarrow \downarrow$ & $\uparrow \uparrow$ & $\uparrow \uparrow$ & $\rightarrow$ & $\rightarrow$ \\
\hline
\end{tabular}

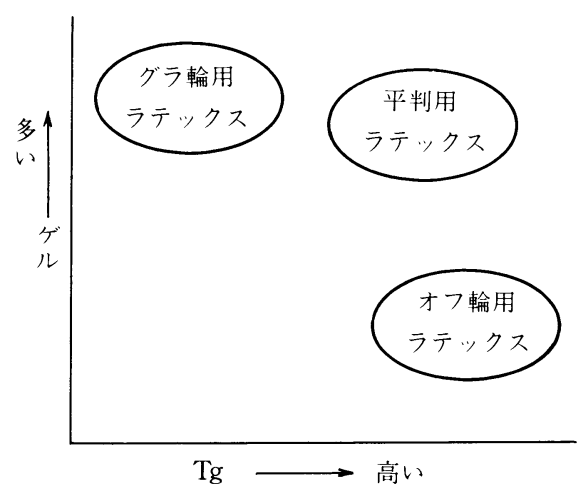


2）オフセット印刷におけるモトリング, 光学的性 質改良

コーターの高速化にともない, 急速乾燥によって生 じる過度のバインダーマイグレーションはインキ受理 不良, 受理么ラの原因となる。このためラテックスの マイグレーションの制御及び塗工層の吸水着肉性のレ ベルアップが必要である。例えばラテックスを両性化 することにより，ピグメントとの相互作用をもたせ, マイグレーションを制御する方法が知られてい

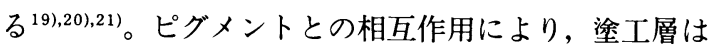
より嵩高くなり吸水着肉性も同時に向上する。塗工紙 の各グレードの差別化及び印刷効果を高めるためラ テックスの白紙光沢, 印刷光沢の改良が課題になって いる。この面でもラテックスを両性化し, 原紙の被覆 性を改良する方法が知られている。

表 8 各種PPの特性

\begin{tabular}{|c|c|c|c|}
\hline & SB-PP & PS-PP & HS-PP \\
\hline 固形分 $(\%)$ & 50 & 48 & 40 \\
\hline 粘度 $\quad 6 \mathrm{rpm}$ & 45 & 122 & 2760 \\
\hline $\begin{array}{l}\text { B型 } \\
\text { (cps)60rpm }\end{array}$ & 27 & 54 & 650 \\
\hline 密度 $\left(9 / \mathrm{cm}^{3}\right)$ & 1.05 & 1.03 & 1.02 \\
\hline 粒径 $\quad(\mu \mathrm{m})$ & $0.3 \sim 0.5$ & 0.5 & 0.55 \\
\hline $\mathrm{pH}^{*}$ & 7.3 & 8.6 & 9.5 \\
\hline 基本組成 & $\begin{array}{l}\text { スチレン- } \\
\text { ブタジエン }\end{array}$ & $\begin{array}{l}\text { ポリスチ } \\
\text { レン }\end{array}$ & $\begin{array}{l}\text { スチレン- } \\
\text { ア }\end{array}$ \\
\hline $\begin{array}{r}\text { ガラス転移点 } \\
\mathrm{T}_{\mathrm{g}}(\mathrm{c})\end{array}$ & 38 & 100 & 105 \\
\hline
\end{tabular}

*印は実測值，その他は各社の技術デー夕による。
プラスチックピグメントは白紙光沢, 平滑度, 着肉 性等を向上させ, 比重も無機顔料が 2.5 前後であるの に対して約 1.0 と低く, 紙の軽量化にも適している。 従来のポリスチレン系プラスチックピグメントに加え, スチレンーブタジエン系バインダーピグメントや最近 開発されたスチレンーアクリル系中空プラスチックピ グメント ${ }^{23,24), 25)}$ が注目され検討されている。各種プラ スチックピグメントの比較データーを表 8, 9, 図 12,

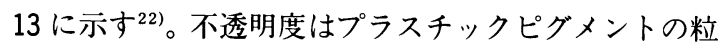
子構造が大きく影響し, 中空のプラスチックピグメン トが特に優れている。今後, 塗工紙はますます軽量化 の方向にあり中空プラスチックピグメントの実用化が 期待される。

表 9 塗料組成 (parts dry weight)

\begin{tabular}{|c|c|c|c|c|c|c|c|c|}
\hline Formulations & 1 & 2 & 3 & 4 & 5 & 6 & 7 & 8 \\
\hline Pigment*1) & 100 & 96 & 95 & 90 & 95 & 90 & 95 & 90 \\
\hline Plastic Pigment & & & & & & & & \\
\hline HS-PP & - & 4 & 5 & 10 & - & - & - & - \\
\hline PS-PP & - & - & - & - & 5 & 10 & - & - \\
\hline SB-PP & - & - & - & -1 & - & - & 5 & 10 \\
\hline Starch*2) & \multicolumn{8}{|c|}{7} \\
\hline SBR Latex & \multicolumn{8}{|c|}{13} \\
\hline Insolubilizer*3) & \multicolumn{8}{|c|}{0.35} \\
\hline Calcium Stearate & \multicolumn{8}{|c|}{0.75} \\
\hline Solid content $\%$ & \multicolumn{8}{|c|}{55.0} \\
\hline
\end{tabular}

*1) Pigment : Clay (LW 90). Calcium carbonate (CL.PCC-A.PCC-C)

*2) Starch : Enzyme converted starch

*3) Insolubilizer : Polyepoxy

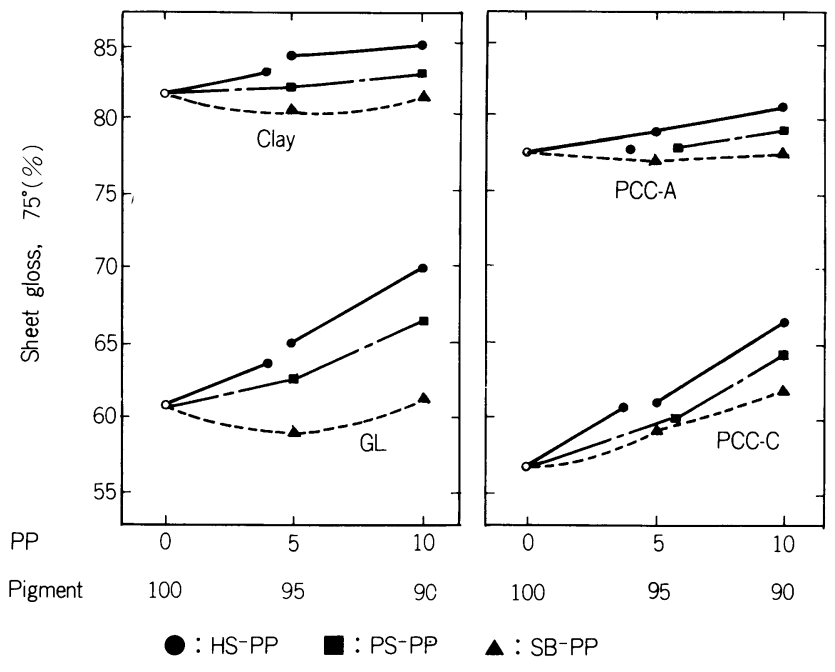

図 12 PP 配合比と白紙光沢度 


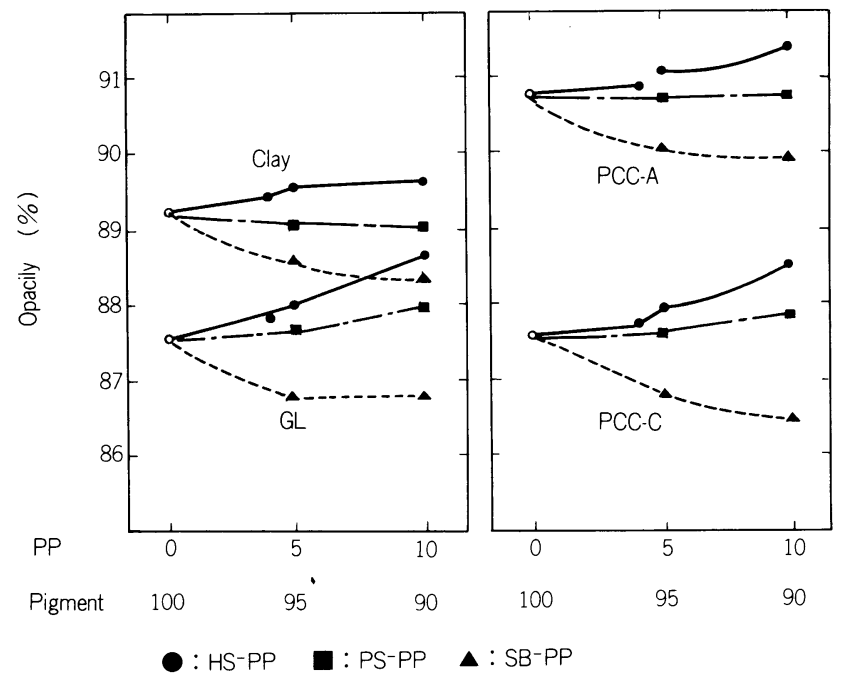

図 13 PP 配合比と不透明度

\section{3）高性能オフ輪ラテックス}

オフ輪の普及及びオフ輪塗工紙の坪量範囲の拡大に ともない, 耐ブリスター適性のレベルアップの要求は 一段と高まっている。耐ブリスタ一適性とドライ強度, 印刷光沢は逆相関の関係にあって, これら物性を総合 したバランスの上で，オフ輪塗工紙の生産時に問題と なるバッキングロール污れ等の操業性も加味した高性 能オフ輪ラテックスが求められている。例えばインキ ビヒクルの浸透を抑えるため，ラテックの粒子系を小 さくして塗工層の空吵を小さくする物理的な方法, ア クリロニトリルのような耐油性モノマーを共重合させ インキのビヒクルの浸透を抑える化学的な方法 ${ }^{26)}$ が知 られている。ポリマーの溶融温度を下げ高温での流れ 特性を改良するためにモノマー組成やゲル量を最適化 したラテックス ${ }^{27), 28)}$, ゲル量の制御のため連鎖移動剤 の使用方法を工夫したラテックス ${ }^{29), 30)}$, 特殊モノマー を使用し操業性を改善したラテックス ${ }^{31)}$, ダブル塗工 でアンダー塗工に使用するラテックスのゲル量を規定 して, 耐ブリスター性と印刷光沢をレベルアップする 方法 ${ }^{32)}$, コア部とシェル部の共重合モノマー組成を変 えて, 異層構造として操業性と耐ブリスタ一性, 印刷 光沢をレベルアップしたラテックス ${ }^{33), 34), 35)}$ 等多くの 特許が公開されている。

4）高性能グラビア用ラテックス

グラビア印刷適性の最大の改良ポイントはハイライ ト部のスペックルのレベルアップである。これはグラ ビア印刷機の広幅化, 高速化が進み従来よりスペック ルにとってより厳しい条件で印刷されること，より印 刷効果の高いグラビア印刷物の需要が高まっているた
めである。スペックルを改良するためには塗工層の表 面平滑性，クッション性を高める方法が一般的にとら れる。クッション性を高めるためブタジエン等のソフ トモノマーの共重合比率をあげ $\mathrm{T}_{\mathrm{g}}$ を下げる方法, 表 面平滑性を上げるため顔料とラテックスの相互作用を もたせ，嵩高い塗工層を形成することをねらった両性 タイプラテックス ${ }^{36,37)}$ が知られている。グラビア用の 塗料配合はオフセット配合と比ベバインダーレベルが 低く，かつ低 $\mathrm{T}_{\mathrm{g}}$ ラテックスを使用することもあり， スーパーカレンダーロールの污れやバッキングロール の污れ等の操業性が問題となるケースが多い。スペッ クル, 操業性とも優れたラテックスの開発が最大の課 題であり, 例えば全体の $\mathrm{T}_{\mathrm{g}}$ は一定にし, コア/シェル 構造をとらせ，ラテックス表面を硬くしたり特殊官能 基モノマーを共重合させる方法 ${ }^{38)}$ が行われている。

5）板紙用ラテックス

包装形態の多様化，加工の高速化により塗工板紙の 糊付け適性, ブリスターパック適性, プレスコート適 性のレベルアップが求められており, 多層構造ラテッ クスによる改良例 ${ }^{40)}$ がある。コート白ボールは $\mathrm{ZnSO}_{4}$ 水溶液によるウェット仕上げ方式が主流であったが, コーターヘッドの改造, プラスチックピグメント, バ インダーピグメントの使用等により, ドライ仕上げ方 式が検討されており，グロスカレンダー污れ等を改良 したラテックス ${ }^{39)}$ ，カゼイン代替やラテックスリッチ 処方での保水性改良をねらったグラフトたんぱくの例 が知られている ${ }^{41), 42)}$ 。 


\section{文献}

1）浜口千里，蓼沼 博：合成ゴム 18 (1) 18, (1976)

2）鴻野銃二郎：紙八技協誌 39 (8) 1, (1985)

3）関矢正良，石塚敏郎，前田大晴，小池敏夫，宮本 健三：接着 28 (9) 27，(1984）

4) 室井宗一, 手塚節造, 中西益彦: 紙パ技協誌 41 (10) 84, (1987)

5) Pinder, J. A. : TAPPI CA Report 36, (8), (1972)

6) Lee D. I. : TAPPI Coating Conference Proceedings, 97, (1974)

7) Lee D. I. : TAPPI Coating Conference Proceedings, $125,(1982)$

8) Lee D. I. : TAPPI Coating Conference Proceedings, 143, (1981)

9）内田 明：紙八゚技協誌 38 (12) 18, (1984)

10) J. Hagymassy, D. I. Lee, A. Schmitt, S. P. Givens, L. Haynes, Jr. : Tappi 61 (1) 59, (1978)

11) Lee, D. I. : “The Influence of Latexes on Rotogravure Printability."

Presented at the panel Discussion for the 1984 Tappi Coating Conference and Tappi Korea 16 (2) 10, (1984)

12) Lee, D. I. : "The effect of Latex on the Rheology of High solids paper Coatings." Presented at the panel Discussion for the 1983 Tappi Coating Conference and Tappi Korea 15 (2) 7, (1983)

13) Van Gilder, R., Lee, D.I., Purfeerst, R., and Allswede, : Tappi 66 (11) 49, (1983)

14）特開昭 61-152897, Dow Chemical
15） " 61-266697, 日本ゼオン

16）紙パルプ技術タイムス 昭和 61 年臨時増刊 $32 \mathrm{p}$

17）特開昭 61-34297, 日本合成ゴム

18）" 62-231096, 日本合成ゴム

19） " 61-268709, 日本合成ゴム

20）" 59-59996, 日本合成ゴム

21）特開昭 59-112094，日本ゼオン，王子製紙

22）日吉公男, 新井富男, 中田幸次郎, 静岡県製紙工 業試験場報告第 8 号, 昭和 61 年 12 月

23）特開昭 56-32513, ローム\&ハース

24）" 60-22873, 大日本インキ

25）" 62-127336, 日本合成ゴム

26） " 50-94034, 住友ノ一ガタック

27） " 54-6575, 日本合成ゴム

28） " 59-3598, 住友ノーガタック

29）" 60-59192, 日本合成ゴム

30) " 61-63794, 日本ゼオン

31）" 62-225395, 日本合成ゴム

32）" 62-162097, 三菱製紙

33）" 57-13679, 旭化成工業

34） " 61-55291, 日本合成ゴム

35）特開昭 62-117897, 日本合成ゴム

36）" 61-225394, 日本合成ゴム

37） " 62-110996, 日本合成ゴム

38） " 62-149997, 日本合成ゴム

39）" 61-22539, 日本合成ゴム

40） " 60-45696, 日本ゼオン

41）" 62-96514, ラルストンピュリナー

42） " 62-197607, ゲンコープインコーポレート 